\title{
Evaluation of macrophage electrophoretic mobility (MEM) test as an indicator of cellular immunity in ocular tumours
}

\author{
AMJAD H. S. RAHI, G. OTIKO, AND A. F. WINDER \\ From the Department of Pathology, Institute of Ophthalmology, London
}

That mammalian cells migrate in an electrical field with differing speeds depending upon their surface charge has been known for some time (Ambrose, 1965). This method of cell electrophoresis was first applied in experimental immunology by Sunderam, Phondke, and Ambrose (1967), who showed that the electrophoretic migration of peritoneal macrophages from a guinea-pig previously immunized with a given antigen is slowed when that antigen is present in the incubation medium. Similarly, the speed of migration of blood lymphocytes in an electrical field is slower in the presence of the antigen to which they are sensitized (Bert, Di Cossano, and Pecco, 1969).

One of the techniques currently available for the in vitro diagnosis of cellular immunity is the macrophage migration inhibition test introduced by David, Al-Askari, Lawrence, and Thomas (1964). When guinea-pig peritoneal macrophages (or, as the test has been modified recently, human blood leucocytes) are put into a capillary tube mounted horizontally in a chamber containing a culture medium they migrate in the space of 12 to 24 hours to form a mushroom, the area of which can be measured. If sensitized T-lymphocytes are present among the macrophages and the antigen to which these lymphocytes are sensitized in vivo are present in the ambient fluid the mushroom formed by the macrophage (or the leucocyte) migration is much reduced, and the reduction in the area (expressed as percentage migration inhibition) is a measure of the degree of cellular immunity or delayed hypersensitivity. This slowing or inhibition of migration is the result of the interaction of the antigen with sensitized, thymus-derived T-lymphocytes, which in turn produce a migration inhibition factor (MIF): this acts on the macrophages and blood leucocytes to alter their metabolism in such a way that their locomotion is slowed down. Field and Caspary (1970) reported an in vitro test for cancer in which. lymphocytes from patients with malignant disease can be stimulated by a basic protein derived from human brain, commonly known as encephalitogenic

Address for reprints: Dr A. H. S. Rahi, Department of Pathology, Institute of Ophthalmology, Judd Street, London WC $\mathrm{W}_{1} \mathrm{H} 9 \mathrm{QS}$ factor (EF), to release a macrophage-slowing factor (MSF) which appears to reduce the electrophoretic mobility of guinea-pig macrophages. This technique, which is now called the macrophage electrophoretic mobility (MEM) test, is in fact a macrophage migration inhibition test performed in an electrical field. The macrophage slowing factor (MSF) is possibly related to the migration inhibition factor (MIF). The technique, however, differs in one important respect: whereas in the migration inhibition test the active movement of the macrophages is altered in the MEM test it is their passive movement in an electrical field which is grossly affected.

The validity of this new in vitro blood test for cancer has been independently confirmed by Pritchard, Moore, Sutherland, and Joslin (1972). Attempts to confirm these findings by Londonbased workers, however, have been unsuccessful (Dale and Mongar, 1974; Forrester, 1974, personal communication). Since ocular melanomas are antigenic (Rahi, I971, 1973; Wong and Oskvig, 1974; Federman, Lewis, Clark, Egerer, and Sarin, 1974) and several eye diseases have a delayed hypersensitivity element, and sometimes mimic choroidal neoplasia, it was thought reasonable to investigate the value of the MEM test in ocular problems. The present investigation was carried out in order to apply, with minor modifications if necessary, this simple test for the diagnosis of ocular tumours and possibly some autoimmune eye diseases.

\section{Materials and methods}

About $20 \mathrm{ml}$ of venous blood was collected from healthy donors, patients with histologically proved choroidal melanoma, and suspected cases of ocular malignancy and placed in siliconized universal bottles containing preservative-free heparin ( $10 \mathrm{U} / \mathrm{ml}$ ). The blood was either received by post or collected by hand. One part of 3 per cent dextran (Pharmacia, Dextran 250) was mixed with three parts of heparinized blood in a polypropylene tube (Sterilin Co) and incubated at $37^{\circ} \mathrm{C}$ for I $\frac{1}{2}$ hours. The supernate was removed and centrifuged at $1200 \mathrm{rpm}$ for 10 minutes and the cellular deposit was washed once in Medium 199 (Wellcome) and re- 
suspended in this medium. The total lymphocyte count was made in a Neubauer counting chamber and the percentage viability was tested by staining with trypan blue, which stains only the dead cells.

Macrophages were prepared from the peritoneal exudate of adult male Hartley guinea-pigs (of the same litter where possible) six days after the injection of $20 \mathrm{ml}$ of sterile liquid paraffin into the peritoneum. Heparinized Hanks's fluid was injected into the peritoneal cavity and the macrophage-rich suspension was aspirated with a $20-\mathrm{ml}$ syringe attached to a perforated polypropylene tube, care being taken not to traumatize the tissues. The cells were passed through a separating funnel and spun at $250 \mathrm{~g}$ for 10 minutes and resuspended in Medium 199.

The mobility of the macrophages was measured with a cytopherometer (Carl Zeiss, West Germany). The capacity of the observation chamber determined the final volume $(3.1 \mathrm{ml})$ of each specimen measured. A constant current of $9 \mathrm{~mA}$ was applied. The observation chamber was maintained at a constant temperature of $23^{\circ} \mathrm{C}$ by an attached thermostat.

\section{TEST SYSTEM}

Antigen $0.1 \mathrm{ml}$ (containing $100 \mu \mathrm{g}$ of encephalitogenic factor (EF) or lymphocytes in presence of antigen (PPD)) was added to $\mathrm{I} \mathrm{ml}$ of Medium $\mathrm{r} 99$ and mixed with $\mathrm{I} \mathrm{ml}$ of lymphocyte suspension containing $0.5 \times 10^{6}$ cells and incubated at $37^{\circ} \mathrm{C}$ for $\mathrm{I}_{2} \frac{1}{2}$ hours. The mixture was then spun off and the supernate added to $\mathrm{I} \mathrm{ml}$ of guinea-pig macrophage containing $10^{7}$ cells. The sample was incubated for $\mathrm{I} \frac{1}{2}$ hours before it was transferred to the electrophoretic chamber. Since at no stage were patients' lymphocytes allowed to come in direct contact with guinea-pig macrophages, irradiation of the sample to inhibit mixed lymphocyte reaction, as suggested in the original technique, was omitted. Moreover, irradiation of macrophages may possibly make them unduly sensitive to the 'slowing factor', so that a weak positive or a border line case may be interpreted as a definite positive response.

Control samples consisted of macrophage alone or macrophage treated with supernate from an unstimulated lymphocyte suspension. All tests were carried out in duplicate.

\section{ELECTROPHORETIC MEASUREMENT}

Macrophages seen under phase contrast in the Zeiss cytopherometer appear as large cells containing several refractile liquid paraffin droplets. The size of these cells is variable and larger cells containing several paraffin droplets appear to move rather slowly in an electrical field. A proper selection of macrophages is therefore essential for a reproducible result and to make comparison between different test systems meaningful. Macrophages of only $16 \mu \mathrm{m}$ size-that is, those fitting one Zeiss eye-piece grid square-were arbitrarily selected for the mobility study and their movement over $32 \mu \mathrm{m}$ (that is, two eye-piece grids) was recorded in seconds with a Sodeco printing clock. By reversing the polarity movement could be measured in both directions of the current, and thus paired timings for each macrophage were obtained. Only those pairs which showed less than ro per cent variation in migration time in the two directions of potential difference were selected for statistical analysis. Ten such pairs for each sample (that is, control or experiment) were selected and the arithmetic mean and the standard deviation calculated.

If $\mathrm{Te}$ is the migration time of the macrophage treated with the supernate from antigen-stimulated lymphocyte suspension (and therefore containing macrophageslowing factor) and $\mathrm{Tc}$ is the migration time when antigen is not added (that is, control) then Te should be greater than $\mathrm{Tc}$ and

$$
\frac{\mathrm{Te}-\mathrm{Tc}}{\mathrm{Tc}} \times 100
$$

gives the percentage slowing of the macrophage and the measure of lymphocyte sensitization to the antigen.

The encephalitogenic factor used was prepared from fresh human brain white matter essentially by the method of Palmer and Dawson (1969).

The working of the instrument and the reliability of the recordings were tested using human red blood cells in phosphate buffer saline $\left(\mathrm{pH}_{7} \cdot 2\right)$. Because of frequent vibrations in the room, owing either to moving traffic or to people working next door, and also owing to microleaks (often not easily detectable) in the electrophoresis chamber, it took us about six months before the mobility of red blood cells could be accurately measured and considered reproducible. A glass disc which provides an air-tight seal between the electrode compartment and the counting chamber was found to be the main cause of drift and faulty movement of the cells. This was later replaced by a plastic disc with a ring washer, designed in our own workshop after discussions with Dr Forrester of the Chester Beatty Cancer Research Institute, London.

After standardization of the instrument with human red blood cells normal guinea-pig macrophages were tested for reproducibility. It was soon realized that selection of macrophages for their size would be the most important criterion for studying mobility differences. Although only macrophages of about $16 \mu \mathrm{m}$ were studied, we found that macrophages from different animals behaved differently and only occasionally could any correlation be achieved. We struggled with this particular variability for another six months with little success, and we now consider it to be one of the major drawbacks of the test. The originators of the test admit that guinea-pigs are susceptible to many diseases that tend to modify the electrophoretic mobility of macrophages and they recommend that investigators should breed their own guinea-pigs and handle them with the strictest antiseptic precautions. In their view, healthiness of the guinea-pigs is of primary importance (Field, 1973).

Guinea-pigs were systemically immunized against PPD and were used to provide both sensitized lymphocytes and peritoneal macrophages for mobility testing.

Another group of guinea-pigs were systemically immunized with crude retinal (photoreceptor) homogenate in Freund's complete adjuvant. At the end of the immunization schedule, which consisted of four intramuscular injections each of visual cell suspension 
from one homologous retina, the animals were injected intraperitoneally with $20 \mathrm{ml}$ of liquid paraffin and the macrophages so harvested were used for MEM study.

The direct effect of human basic myelin protein (that is, the encephalitogenic factor) on the mobility of guinea-pig macrophages was measured in a separate study.

Blood lymphocytes from four histologically proved cases of choroidal melanoma and six strongly suspected cases of uveal melanoma (one of which was later proved to be a malignant lesion) were included in the study. Peripheral lymphocytes from Io patients with nonneoplastic eye diseases such as uveitis, scleritis, posttraumatic endophthalmitis, and giant cell arteritis and from two healthy laboratory workers were used as control.

\section{Results}

Even when only macrophages of a particular size were studied the average migration time varied from one animal to another and especially from one batch to another. The migration time over a distance of $32 \mu \mathrm{m}$ varied from as low as $1 \cdot 7 \mathrm{~s}$ to as high as $6.8 \mathrm{~s}$.

One group of animals immunized with PPD showed 13 per cent slowing of the macrophages when these cells were treated with supernate containing macrophage slowing factor (MSF) (Table I). The other group of animals, on the contrary, did not show any slowing-indeed, an increase in speed was noted (Table II).

Lymphocytes obtained from animals immunized

Table I Ten paired-timings showing effect on mobility of sensitized guinea-pig peritoneal macrophages after release of macrophage slowing factor (MSF) from lymphocytes in presence of antigen (PPD) (times in seconds)

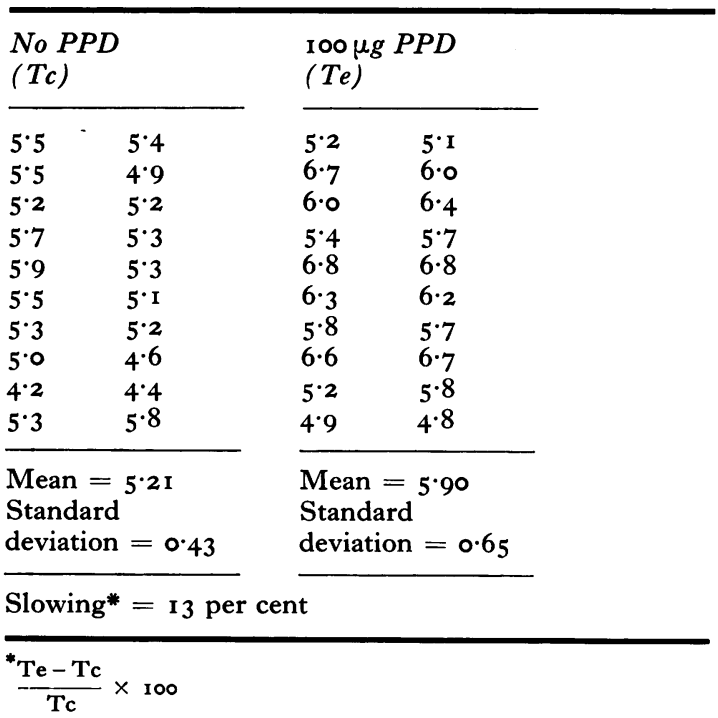

against retinal antigen produced a slowing factor at Io $\mathrm{mg}$ concentration per sample which retarded the mobility of the macrophages by 14 per cent. At higher antigen concentration the effect was less pronounced (Table III).

Table II Ten paired-timings showing effect on mobility of sensitized guinea-pig peritoneal macrophages after release of macrophage slowing factor (MSF) from lymphocytes in presence of antigen (PPD) (times in seconds)

\begin{tabular}{|c|c|c|c|c|c|}
\hline \multicolumn{2}{|c|}{$\begin{array}{l}\text { No } P P D \\
(T c)\end{array}$} & \multicolumn{2}{|c|}{ 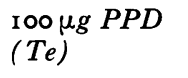 } & \multicolumn{2}{|c|}{$\begin{array}{l}200 \mu g P P D \\
(T e)\end{array}$} \\
\hline $5 \cdot 9$ & $6 \cdot 0$ & $4 \cdot 6$ & $4 \cdot 2$ & $4 \cdot 2$ & 4.4 \\
\hline $4 \cdot 9$ & $4 \cdot 8$ & $4 \cdot 6$ & $4 \cdot 5$ & $5 \cdot 3$ & $5 \cdot 1$ \\
\hline $5 \cdot 8$ & $6 \cdot 1$ & $4 \cdot 5$ & $4 \cdot 0$ & $4 \cdot 5$ & $4 \cdot 5$ \\
\hline $5 \cdot 5$ & $4 \cdot 9$ & $3 \cdot 8$ & 377 & $4 \cdot 9$ & $4 \cdot 3$ \\
\hline 5.0 & 4.9 & $4 \cdot 2$ & $3 \cdot 8$ & $5 \cdot 0$ & $4 \cdot 6$ \\
\hline $4 \cdot 6$ & $4 \cdot 9$ & $4 \cdot 4$ & $3 \cdot 9$ & 3.9 & $3 \cdot 4$ \\
\hline $5 \cdot 6$ & $5 \cdot 2$ & $4 \cdot 4$ & $4 \cdot 2$ & $4 \cdot 9$ & $4 \cdot 4$ \\
\hline $5 \cdot 1$ & $5 \cdot 3$ & $5 \cdot 2$ & 5.5 & $5 \cdot 7$ & $5 \cdot 2$ \\
\hline $3 \cdot 8$ & $4 \cdot 3$ & 4.4 & $4^{\circ} \circ$ & $4 \cdot 6$ & $4 \cdot 4$ \\
\hline $4 \cdot 6$ & $4 \cdot 4$ & $4 \cdot 8$ & $4 \cdot 5$ & $4 \cdot 8$ & $4 \cdot 7$ \\
\hline \multirow{2}{*}{\multicolumn{2}{|c|}{$\begin{array}{l}\text { Mean }=5.08 \\
\text { Standard } \\
\text { deviation } \\
=0.60\end{array}$}} & \multirow{2}{*}{\multicolumn{2}{|c|}{$\begin{array}{l}\text { Mean }=4.36 \\
\text { Standard } \\
\text { deviation } \\
=0.45\end{array}$}} & \multirow{2}{*}{\multicolumn{2}{|c|}{$\begin{array}{l}\text { Mean }=4.64 \\
\text { Standard } \\
\text { deviation } \\
=0.51\end{array}$}} \\
\hline & & & & & \\
\hline \multicolumn{2}{|c|}{ Slowing } & \multicolumn{2}{|c|}{ - I 4 per cent } & \multicolumn{2}{|c|}{-8 per cent } \\
\hline
\end{tabular}

Table III Typical record of 10 paired-timings showing effect on mobility of sensitized guinea-pig peritoneal macrophages after release of macrophage slowing factor (MSF) from lymphocytes in presence of retinal antigen (time in seconds)

\begin{tabular}{|c|c|c|c|c|c|}
\hline \multicolumn{2}{|c|}{$\begin{array}{l}\text { No antigen } \\
(T c)\end{array}$} & \multicolumn{2}{|c|}{$\begin{array}{l}\text { 1o mg crude } \\
\text { retinal extract } \\
(T e)\end{array}$} & \multicolumn{2}{|c|}{$\begin{array}{l}20 \text { mg crude } \\
\text { retinal extract } \\
(\mathrm{Te})\end{array}$} \\
\hline $4 \cdot 9$ & $4 \cdot 4$ & $5 \cdot 4$ & $5^{\circ} 9$ & $4 \cdot 0$ & $4 \cdot 5$ \\
\hline $4 \cdot 4$ & $4 \cdot 5$ & $4 \cdot 8$ & $5 \cdot 2$ & $4 \cdot 7$ & $4 \cdot 7$ \\
\hline $4 \cdot 5$ & $4 \cdot 7$ & $5 \cdot I$ & $4 \cdot 8$ & $5 \cdot 4$ & $5 \cdot 0$ \\
\hline $4 \cdot 2$ & $3 \cdot 8$ & $5 \cdot 3$ & $5^{\circ} \circ$ & $4 \cdot 4$ & $4 \cdot 0$ \\
\hline $4 \cdot 8$ & $4 \cdot 7$ & $4 \cdot I$ & $4 \cdot 3$ & $5 \cdot 0$ & $4 \cdot 5$ \\
\hline $3 \cdot 8$ & $4 \cdot 2$ & $4 \cdot 5$ & $4 \cdot 7$ & $5 \cdot 2$ & $4 \cdot 8$ \\
\hline $4 \cdot 1$ & $3 \cdot 9$ & $5 \cdot I$ & $5 \cdot 0$ & $4^{\cdot} 9$ & $4 \cdot 6$ \\
\hline $4 \cdot 4$ & $4 \cdot 5$ & $4 \cdot 6$ & $5 \cdot I$ & $4 \cdot 3$ & $3 \cdot 8$ \\
\hline $3 \cdot 7$ & $3 \cdot 8$ & $4 \cdot 5$ & $4 \cdot 4$ & $5^{\cdot} \mathrm{I}$ & $5 \cdot 2$ \\
\hline $4 \cdot I$ & $4 \cdot 2$ & $6 \cdot 2$ & $5 \cdot 6$ & $5^{\circ} \circ$ & $4 \cdot 5$ \\
\hline \multicolumn{2}{|c|}{$\begin{array}{l}\text { Mean } 4.28 \\
\text { Standard } \\
\text { deviation } \\
=0.25\end{array}$} & \multicolumn{2}{|c|}{$\begin{array}{l}\text { Mean } 4.87 \\
\text { Standard } \\
\text { deviation }\end{array}$} & \multicolumn{2}{|c|}{$\begin{array}{l}\text { Mean } 4 \cdot 68 \\
\text { Standard } \\
\text { deviation }\end{array}$} \\
\hline \multicolumn{2}{|c|}{$=0.35$} & \multicolumn{2}{|c|}{$=0.44$} & \multicolumn{2}{|c|}{$=0.43$} \\
\hline \multicolumn{2}{|c|}{ Slowing } & \multicolumn{2}{|c|}{ I 4 per cent } & \multicolumn{2}{|c|}{9 per cent } \\
\hline
\end{tabular}


The human encephalitogenic factor (EF) acting directly on guinea-pig macrophages had a variable effect on the general mobility. Although the slowing was generally below 3 per cent, on some occasions a slowing up to 7 per cent was noted (Table IV).

Lymphocytes from melanoma patients treated with $100 \mu \mathrm{g}$ of EF seemed to release a factor which slowed the macrophage mobility by 7 per cent as opposed to 3 per cent in the control tube (Table V). Similar but inconsistent results were obtained with lymphocytes from non-neoplastic eye diseases.

\section{Discussion}

The fact that many human malignant neoplastic lesions contain tumour-associated antigens has stimulated many attempts to develop immunological methods of diagnosing cancer. The Field and Caspary MEM test for cancer has been claimed to produce remarkable consistency of diagnostic accuracy. If reproducible this test would clearly represent another important clinical advance in the diagnosis of ocular tumours as well as of neoplasms in other parts of the body. The technique, however, has not received widespread attention since its first description in 1970.

Pritchard, Moore, Sutherland, and Joslin (1973), who first confirmed the reproducibility of this test in 1972, have now modified the original technique and believe their modified MEM test gives more consistent results because it gives greater slowing of the macrophages. The modified MEM technique has been examined by Lewkonia, Kerr, and Irvine

Table IV Typical record of Io paired-timings showing direct effect of human basic myelin protein (encephalitogenic factor, EF) on mobility of guineapig peritoneal macrophages (times in seconds)

\begin{tabular}{|c|c|c|c|}
\hline \multicolumn{2}{|c|}{$\begin{array}{l}\text { No EF } \\
(T c)\end{array}$} & \multicolumn{2}{|c|}{$\begin{array}{l}\text { EF roo } \mu g \text { sample } \\
(T e)\end{array}$} \\
\hline $4 \cdot 2$ & $4 \cdot 2$ & $4^{\circ} 9$ & 4.5 \\
\hline $4 \cdot 6$ & 47 & 5.7 & $5 \cdot 5$ \\
\hline 4.4 & $4 \cdot 8$ & $5 \cdot 0$ & $5 \cdot 6$ \\
\hline $4 \cdot 6$ & $4 \cdot 6$ & $5 \cdot 7$ & 5.5 \\
\hline $4 \cdot 8$ & 4.5 & $5 \cdot 2$ & 4.9 \\
\hline $5 \cdot 1$ & $5 \cdot 1$ & 4.5 & $4 \cdot 8$ \\
\hline 5.4 & $5 \cdot I$ & $5 \cdot 0$ & $5 \cdot I$ \\
\hline 4.9 & $5 \cdot 4$ & $5 \cdot 3$ & $5^{\cdot} \mathrm{I}$ \\
\hline 5.0 & $4 \cdot 5$ & $6 \cdot 0$ & 5.5 \\
\hline $5 \cdot 5$ & $5 \cdot 0$ & $4 \cdot 8$ & $5 \cdot 0$ \\
\hline \multicolumn{2}{|c|}{$\begin{array}{l}\text { Mean }=4.82 \\
\text { Standard deviation } \\
\quad=0.38\end{array}$} & \multicolumn{2}{|c|}{$\begin{array}{l}\text { Mean }=5.18 \\
\text { Standard deviation } \\
\quad=0.4 \mathrm{I}\end{array}$} \\
\hline
\end{tabular}

Slowing $=7$ per cent
Table V Typical record of 10 paired-timings showing effect on mobility of guinea-pig peritoneal macrophages after incubation with macrophage slowing factor (MSF) released from peripheral lymphocytes of an ocular melanoma patient in presence of human basic myelin protein (encephalitogenic factor, EF) (times in seconds)

\begin{tabular}{|c|c|c|c|c|c|c|c|}
\hline \multicolumn{2}{|c|}{$\begin{array}{l}\text { Macrophage } \\
\text { alone } \\
(T c)\end{array}$} & \multicolumn{2}{|c|}{$\begin{array}{l}\text { Macrophage } \\
+ \text { no MSF } \\
\text { (unstimulated } \\
\text { supernate) } \\
\text { (Te) }\end{array}$} & \multicolumn{2}{|c|}{$\begin{array}{l}\text { Macrophage } \\
+M S F \\
(\text { Ioo } \mu g E F) \\
(T e)\end{array}$} & \multicolumn{2}{|c|}{$\begin{array}{l}\text { Macrophage } \\
+M S F \\
(200 \mu g E F) \\
(T e)\end{array}$} \\
\hline $5 \cdot I$ & $4 \cdot 5$ & $4 \cdot 0$ & $5 \cdot 3$ & $5 \cdot I$ & $4 \cdot 7$ & $4 \cdot 3$ & $4 \cdot 3$ \\
\hline $4 \cdot 0$ & $4 \cdot 3$ & $4 \cdot 7$ & $4 \cdot 5$ & $5 \cdot 4$ & $5^{\cdot I}$ & $4 \cdot 4$ & $4 \cdot 2$ \\
\hline $4 \cdot 9$ & $4 \cdot 9$ & $4 \cdot 5$ & 4.7 & $4 \cdot 9$ & $4 \cdot 6$ & $4 \cdot 9$ & $4 \cdot 5$ \\
\hline $5 \cdot 2$ & 4.9 & $4 \cdot I$ & $4 \cdot 3$ & $5 \cdot 2$ & $4 \cdot 8$ & $4 \cdot 5$ & $5 \cdot 2$ \\
\hline $3 \cdot 8$ & $3 \cdot 8$ & $5 \cdot 6$ & $5 \cdot 1$ & $5 \cdot I$ & $4 \cdot 9$ & $4 \cdot 9$ & $4 \cdot 4$ \\
\hline $4 \cdot 0$ & $4 \cdot 2$ & $5 \cdot I$ & $5 \cdot 6$ & $4 \cdot 2$ & $3 \cdot 7$ & $5 \cdot 0$ & $4 \cdot 8$ \\
\hline $3 \cdot 6$ & $3 \cdot 7$ & $4 \cdot 7$ & $4 \cdot 8$ & $5 \cdot 1$ & $5 \cdot 6$ & $4 \cdot I$ & $4 \cdot 6$ \\
\hline $5 \cdot 1$ & $4 \cdot 8$ & $4 \cdot 7$ & $4 \cdot 3$ & 4.7 & $4 \cdot 8$ & $4 \cdot 6$ & $5 \cdot 1$ \\
\hline $5 \cdot 4$ & $4 \cdot 8$ & $5 \cdot 7$ & $5 \cdot 2$ & $4 \cdot 6$ & $4 \cdot 6$ & $4 \cdot 9$ & $4 \cdot 4$ \\
\hline $5 \cdot 5$ & $4 \cdot 9$ & $3 \cdot 9$ & $4 \cdot 2$ & $5 \cdot 2$ & $5 \cdot 7$ & $3 \cdot 9$ & $4 \cdot 1$ \\
\hline \multirow{2}{*}{\multicolumn{2}{|c|}{$\begin{array}{l}\text { Mean }= \\
4.57 \\
\text { Standard } \\
\text { deviation } \\
=0.59\end{array}$}} & \multirow{2}{*}{\multicolumn{2}{|c|}{$\begin{array}{c}\text { Mean }= \\
4.75 \\
\text { Standard } \\
\text { deviation } \\
=0.54\end{array}$}} & \multirow{2}{*}{\multicolumn{2}{|c|}{$\begin{array}{l}\text { Mean }= \\
4.90 \\
\text { Standard } \\
\text { deviation } \\
=0.46\end{array}$}} & \multirow{2}{*}{\multicolumn{2}{|c|}{$\begin{array}{l}\text { Mean }= \\
4.55 \\
\text { Standard } \\
\text { deviation } \\
=0.36\end{array}$}} \\
\hline & & & & & & & \\
\hline \multicolumn{2}{|c|}{ Slowing } & \multicolumn{2}{|c|}{3 per cent } & \multicolumn{2}{|c|}{7 per cent } & \multicolumn{2}{|c|}{ No slowing } \\
\hline
\end{tabular}

(1974). They took into account a claim by Field, Caspary, and Smith (1973) that human tumours contain a basic protein to which the patients' lymphocytes are sensitized. This cancer basic protein $(\mathrm{Ca} \mathrm{BB})$ is believed to provide more reliable results than myelin basic protein. Although Goldstone (1973) confirmed this finding, Lewkonia and his associates (1974) reported that the modified MEM test failed to discriminate between groups of patients with benign and malignant chest diseases. By the originators' own acceptance (Field and others, 1973), some difficulties and possibilities of misdiagnosis exist when dealing with cases of multiple sclerosis, sarcoidosis, Crohn's disease, ulcerative colitis, asthma, myasthenia gravis, influenzal infection, and asbestosis. Sometimes lymphocytes from normal individuals may show a false positive reactivity.

One of the greatest problems of this test is that of logistics. Operation of the Zeiss cytopherometer is difficult to standardize and much depends on the subjective skill and experience of the operator. Microleaks, 'drift', and bubble in the measuring chamber are recurrent problems. Size and functional heterogeneity of macrophages (Walker, 1974) is another problem. A third variable, which is very 
important in the context of immunodiagnosis of cancer, is the reliability of the antigen. It seems that both myelin and cancer basic proteins are weak antigens and, unless some better antigen is available, the macrophage electrophoretic mobility test in its present form is not reproducible. Although some slowing is observed in cases of ocular melanomas a similar change is also seen in some inflammatory eye diseases. Possibly, however, the disparity between our results and those proviously reported by others may be the result of some technical failure. But this seems unlikely because we obtained a definite inhibition of migration when retinal extracts were used as antigens in specifically immunized animals. A similar result has been obtained in a case of uveitis when human ocular extracts were used (Jenssen, Jenssen, Kohler, and Friemel, 1976).

\section{Summary}

The macrophage electrophoretic mobility (MEM) test of Field and Caspary did not clearly separate patients with ocular neoplastic disease from those with inflammatory disease, although there was some indication of discrimination between choroidal melanoma and ocular inflammation. In our hands the test failed to give a reproducible result for the immunodiagnosis of ocular malignancy. The technique, however, seems to provide some indication of delayed hypersensitivity in experimental inflammatory eye diseases when relatively pure antigens are used.

We are most grateful to Professor N. H. Ashton, CBE, FRS, for his advice and encouragement, and to the Cancer Research Campaign for their generous grant for the purchase of a cytopherometer.

\section{References}

AMBrose, E. J. (1965) 'Cell Electrophoresis'. Churchill, London

BERT, G., DI COSSANO, D. L., and PECCO, P. (I969) Clin. exp. Immunol., 5, 669

DALE, M. M., and MONGAR, J. (1974) Brit. F. Cancer, 28 (suppl. I), 240

DAVID, J. R., AL-ASKARI, S., LAWRENCE, H. S., and THOMAS, L. (1964) $\mathcal{F}$. Immunol., 93, 264

federman, J. L., LeWiS, M. G., Clark, W. H., Egerer, I., and SARIN, K. (1974) Trans. Amer. Acad. Ophthal.

Ololaryng., 78, 787

FIELD, E. J. (1973) Brit. F. Cancer, 28 (suppl. I), 240

-

, - and SMiTh, K. s. (1973) Brit. F. Cancer, 28 (suppl. I), 208

FORRESTER, J. A. (1974) Personal communication

GoldSTONE, A. H. (1973) Brit. F. Cancer, 28 (suppl. 2), 24I

JENSSEN, R., JENSSEN, H. L., KOHLER, H., and FRIEMEL, H. (r976) Modern Probl. Ophthal. (Basel), 16, 259

LEWKONIA, R. M., KERR, E. J. L., and IRVINE, W. J. (I974) Brit. F. Cancer, 30, 532

PALMER, F. B., and DAWSON, R. M. C. (1969) Biochem. F., III, 629

PRITCHARD, J. A. V., MOORE, J. L., SUTHERLAND, W. H., and JOSLIN, C. A. v. (1972) Lancet, 2, 627

RAHI, A. H. S. (I97I) Brit. $\mathcal{F}$. Ophthal., 55, 793

(1973) Trans. ophthal. Soc. U.K., 93, 79

SUNDERAM, K., PHONDKE, G. P., and AMBROSE, E. J. (1967) Immunology, 12, 2 I

WALKER, W. S. (1974) Ibid., 26, 1025

WONG, I. G., and OSKvig, R. M. (1974) Arch. Ophthal., 92, 98 